BIOTROPIA NO. 16, $2001: 1$ - 9

\title{
IN VITRO PROPAGATION OF ANGIOPTERIS EVECTA USING SPORES
}

\author{
DAMIENCUPITT,POONAM BHATIA* AND NANJAPPA ASHWATH \\ Primary Industries Research Centre, School of Biological and Environmental Sciences, \\ Central Queensland University, Rockhampton, QLD 4702, Australia
}

\begin{abstract}
Techniques of establishing Angiopleris evecta plants in vitro were studied. Soaking of $A$. evecta spores in water for 24 hours markedly reduced spore contamination. Soaking of the spores in $1-2 \%$ of sodium hypochlorite for less than 5 minutes allowed satisfactory disinfestation without affecting spore viability. Lower concentration of minerals (1/4 MS), presence of charcoal in the medium and exposure of the spores to light were crucial for spore germination and gainetophytc development of $A$. evecta.
\end{abstract}

Keywords: Angiopleris evecta I King fern / spore / MS medium / bleach / light / tissue culture / sporophyte / gamctophytc

\section{Abbrevations}

BA - benzylaminopurine; BB - Bold's basal medium; pCPA - para-chlorophenoxyacetic acid; 2,4-D - 2,4-dichlorophenoxyacetic acid; IAA - indoleacetic acid; IBA - indolebutyric acid; Kinetin -6-furfurylaminopurine; MM - Moss's mineral medium; MS - Murashige \& Skoog media; NAA - naphthaleneacetic acid; NOA - naphthoxyacetic acid.

\section{INTRODUCTION}

The fern and fern allies are the surviving members of the earliest lineages of vascular plants. None of these primitive plants produce either seeds or flowers; instead they reproduce via single-celled spores. Ferns are usually found in moist terrestrial or aquatic environments and their size may vary from a few centimeters to many meters.

Angiopteris evecta is known as King fern or Giant fern and it belongs to the family Marattiaceae. It is a magnificent fern, the fronds are reputedly largest in the world, and are about $5 \mathrm{~m}$ long, arching, semi-weeping, bi-pinnate, and glossy (Figure la). Lower pinnules have earlike lobes at the base. Sporangia always occur

\footnotetext{
‘* Corresponding author : e-mail address : p.bhatia@CQU.Edu.Au Fax: 61-7-4930 9255
} 


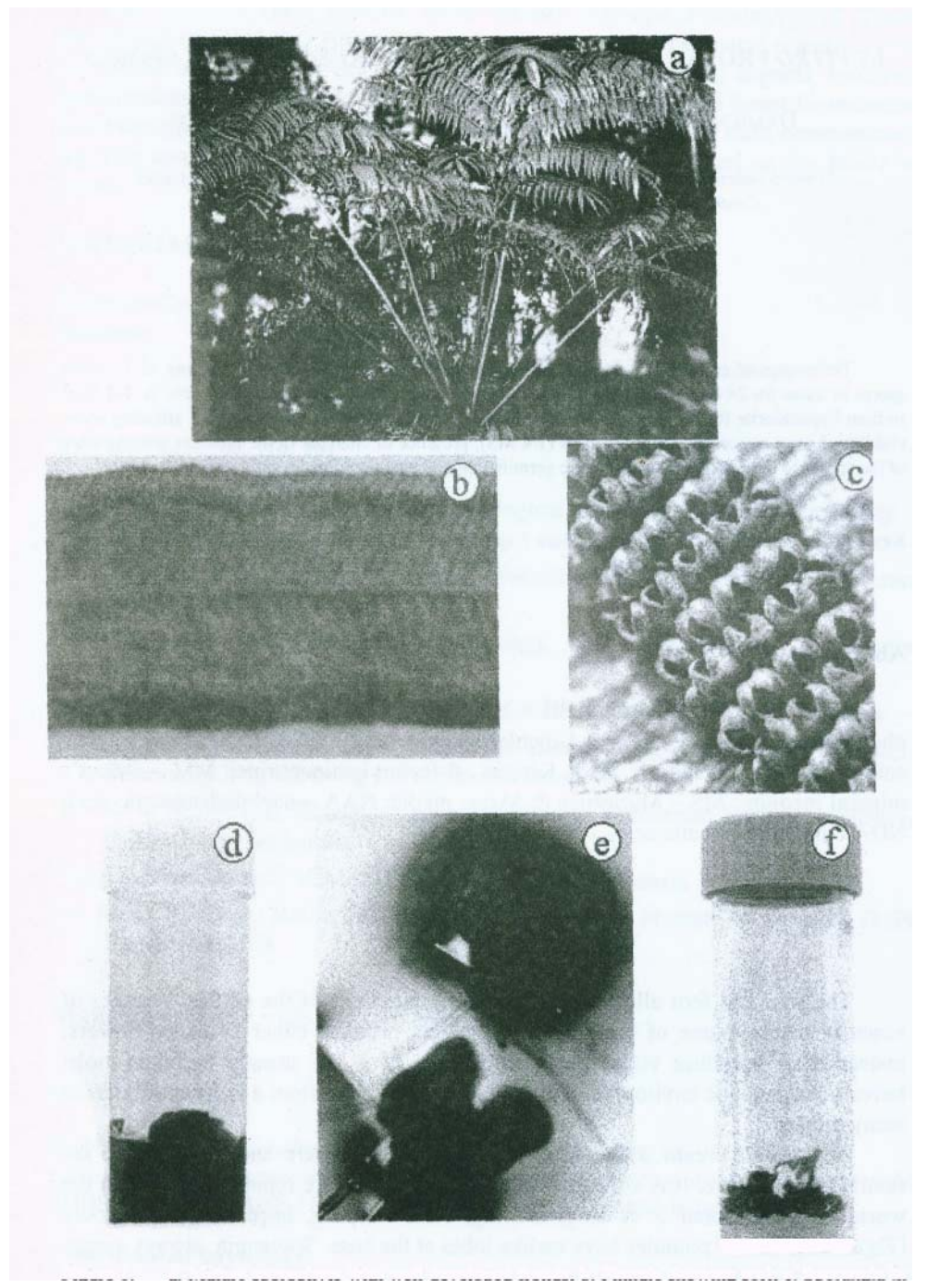

Figure 1. a. Mature sporophyte with well developed fronds; b. Pinnule showing sori; c. Sporangia in dense clusters; d\&e. Developing gametophytes in MS Vi c medium; f. Germinating sporophyte from gametophyte. 
in dense clusters of five to eight opposite pairs (Figure Ib \& Ic). The King fern is found in Australia (Queensland and New South Wales), Malaysia, Polynesia and southern and northeastern parts of India. It also occurs in New Guinea and Indonesia (S. Marsterson; Department of E.P.A., Rockhampton, Pers. com.). In northeastern parts of India, the massive stem is cooked and eaten by the tribes. An intoxicating drink called 'Ruchshi' is also made out of it. The plant yields aromatic oil that is used for perfuming coconut oil in south sea islands (Manickam and Irudayaraj 1992). Conventionally, King ferns are almost impossible to propagate from spores but may be reproduced vegetatively from the fleshy earlike projections which are commonly known as auricles. Plant development is very slow and it may take 12 months or more before a small frond and sufficient roots develop to support the plant (Blomberry and Maloney 1994). Tissue culture can prove to be the fastest and the most effective method of multiplication of the King fern.

Studies on in vitro spore propagation and culture media requirements of different ferns have been conducted by Bernabe et al. (1999); Amoroso and Amoroso (1998); Fernandez et al. (1997); Goller and Rybczynski (1995) and Dong and $\mathrm{Su}$ (1993). Since spores remain the only source of fern propagation, considerable importance has been placed on spore disinfestation and culture media selection for different ferns. Fernandez et al. (1997) observed optimal growth of Blechnum spicant gametophytes in MS (Murashige and Skoog 1962) liquid medium spread over a 2\% agar and exposed to 16 hours of light. Borelli et al. (1990) used both calcium and sodium hypochlorite solution for disinfesting spores and they obtained the best results with $2 \%$ sodium hypochlorite solution. Borelli et al. (1990) also observed better germination of the ferns Cyathea schanschin and Dicksonia sellowiana on John and Knop's media after 4-8 weeks, with the prothalli developing 30-40 days later. In a similar study, Goller and Rybczynski (1995) disinfested spores of Cyathea australis using 3\% chloramine with Tween. They reported better germination of spores on Anderson's medium supplemented with $80 \mathrm{mg} \mathrm{T}^{1}$ of adenine sulfate solidified by $0.8 \%$ agar.

No studies are currently available for A. evecta either for spore disinfestation or for selecting suitable culture medium. The present study was carried out to optimize spore disinfestation procedures and to determine suitable culture medium and growth conditions for establishment of $A$. evecta in tissue culture.

\section{MATERIALS AND METHODS}

\section{Collection and Storage of Spores}

Recently, matured pinnules containing sori were collected fresh from the Rockhampton City Council Botanical Garden, Rockhampton, Australia. After a close microscopic examination, closed sori containing spores were isolated from the 
BIOTROPIA NO. 16, 2001

fronds for disinfestation. Another set of pinnules was stored in a brown paper bag to allow drying without fungal infection.

\section{Effect of Soaking Spores on Contamination}

The sori were separated from the pinnulus by scraping with a scalpel. The released sporangia were then collected onto a piece of paper. These sporangia were exposed to three treatments. In Treatment 1, sporangia were filtered through a 106 um sieve using demineralised water and the filtrate was collected in a glass jar. The sporangia were allowed to soak in water for approximately 24 hours. Once soaked, the spore solution was microfuged $\left({ }^{x} 10,000 \mathrm{rpm}\right)$ for five minutes to concentrate the spores prior to sterilisation (sieved and soaked). The spore solution (1 ml) was inoculated onto agar plates to test for contamination and germination. In Treatment 2, the unsieved sporangia were used, and they were soaked in sterile water for 24 hours before microfuging as in Treatment 1 (not sieved but soaked). In Treatment 3, plant debris were removed by sieving and the spores were not soaked in water (sieved but not soaked). The rest of the operations were the same as for Treatment 1 . In Treatment 4, spores were neither sieved nor soaked (neither sieved nor soaked).

\section{Spore Disinfestation}

Two concentrations (1\% and $2 \%$ ) of sodium hypochlorite were used for disinfestation, with the exposure times of 3, 5, 7 and 9 minutes. A known volume (1 $\mathrm{ml}$ ) of solution containing sporangia was placed in an Eppendorf tube and $1.5 \mathrm{ml}$ of $1 \%$ or $2 \% \mathrm{NaOCl}$ was added. After 30 seconds of soaking, the Eppendorf tube was centrifuged for 3 minutes. One milliliter solution was removed from the top of the Eppendorf tube and a milliliter of sterile water was added. The contents were centrifuged again for 2 minutes. The washing with sterile water was repeated 4 times, to remove all traces of $\mathrm{NaOCl}$ prior to inoculation.

Inoculation

Using aseptic bench top tunnel technique, culture tubes (50 ml capacity, plastic) were inoculated with two drops of spore solution and the tubes sealed before being placed in a controlled environment room.

Media

Media with low nutrient content were selected, because the spores, like seeds, contain all required nutrients for early growth. Wide ranges of media were used. These include MS, MSc (MS media + 1 g/L charcoal), MS\%c (MS medium with $V^{*}$ nutrients $+1 /$ « sugar +1 g/L charcoal), MS low (MS medium + low hormones*), MS'/z low (MS medium with Vi nutrients + low hormones*), MS\% low (MS medium 
with 1/4 nutrients + low hormones*), FN (fern normal), Bold's basal (Bischoff and Bold 1963) and Moss's mineral media.

*Here De Fossard's (1981) broad spectrum low hormones were used. Low hormones consisted of Auxins (IAA+IBA+NAA+NOA+2,4-D+pCPA; $0.1 \mathrm{uM}$ each) and Cytokinins (BAP+Kinetin; $0.1 \mathrm{uM}$ each).

\section{Incubation}

One set of inoculated tubes was randomly stacked in a clear plastic bag and incubated in a controlled environment room (CER) at $30{ }^{\circ} \mathrm{C}$ with a light intensity of $100 \mathrm{uEm} \sim^{2} \mathrm{~S}^{\sim}$. The CER was maintained at a photoperiod of 12 hours light and 12 hours dark. The second set of tubes was sealed within a black plastic bag to simulate dark environment that is often found in dense rainforest floor where mature ferns are usually found. Both sets of tubes were placed side by side in the CER to ensure that they were exposed to similar climatic conditions except for light.

\section{RESULTS}

\section{Effect of Soaking on Contamination and Spore Germination}

Pre-soaking of spores for 24 hours before disinfestation reduced contamination. The contamination rate could be reduced to as low as $3 \%$ with pre-soaking treatment alone. Most of this contamination was caused by fungi (Penicillium sp. and Aspergillus sp.) and rarely by bacteria. Contamination was as high as $75 \%$ when the spores were neither sieved nor soaked. The sieving and soaking reduced the contamination rate to $13 \%$ (Table 1). Sieving had very little effect on contamination, but the soaking markedly reduced the contamination rate.

Table 1. Effect of pre-soaking treatments on contamination and spore germination of $A$. evecta

\begin{tabular}{lcccc}
\hline \hline & \multicolumn{4}{c}{ Pre-disinfestation treatments } \\
\cline { 2 - 5 } & $\begin{array}{c}\text { Soaked and } \\
\text { sieved }\end{array}$ & $\begin{array}{c}\text { Soaked but } \\
\text { not sieved }\end{array}$ & $\begin{array}{c}\text { Not soaked but } \\
\text { sieved }\end{array}$ & $\begin{array}{c}\text { Not soaked } \\
\text { Not sieved }\end{array}$ \\
\hline $\begin{array}{l}\text { Number of culture tubes } \\
\text { inoculated }\end{array}$ & 99 & 72 & 32 & 8 \\
\hline Contaminated tubes & 12 & 2 & 20 & 6 \\
\hline$\%$ Contamination & 13 & 3 & 63 & 75 \\
\hline $\begin{array}{l}\text { No. of tubes showing } \\
\text { spore germination }\end{array}$ & 11 & 1 & 15 & 13 \\
\hline$\%$ germination & 11 & 1 & 47 & \\
\hline
\end{tabular}




\section{Response of $A$. evecta spores to $\mathrm{NaOCl}$}

The degree of contamination varied from $0 \%$ to $38 \%$, with $1 \% \mathrm{NaOCl}$ and from $0 \%$ to $9 \%$ at $2 \% \mathrm{NaOCl}$ (Table 2). Exposure of King fern spores to 1 or $2 \%$ $\mathrm{NaOCl}$ for either 7 or 9 minutes resulted in complete disinfestation. However, none of these spores germinated when the exposure time exceeded 5 minutes. Thus, the treatment of King fern spores with $2 \% \mathrm{NaOCl}$ solution for less than 5 minutes appear to provide the best results. The tubes that were inoculated with untreated spores were fully contaminated suggesting that disinfection is a must for King fern spores.

Table 2. Contamination status of $A$. evecta spores in response to naOCI concentration and time of exposure (number of tubes used per treatment varies from 8 to 38)

\begin{tabular}{lcccccccc}
\hline & \multicolumn{7}{c}{ Exposure time (minutes) } \\
\cline { 2 - 9 } & & 3 & & & 5 & 7 & 9 \\
\hline $\begin{array}{l}\mathrm{NaOCl} \\
\text { concentration (\%) }\end{array}$ & 1 & 2 & 1 & 2 & 1 & 2 & 1 & 2 \\
\hline $\begin{array}{l}\% \text { tubes } \\
\text { contaminated }\end{array}$ & 25 & 7 & 38 & 9 & 0 & 0 & 0 & 0 \\
\hline
\end{tabular}

\section{Effect of Culture Media on Spore Germination}

The highest germination (69\%) was observed in MSVic medium followed by Moss's mineral medium (25\%), Hold's basal medium (17\%), MS 'Alow (4\%) and MS'/tlow (0\%) (Table 3). Spores failed to germinate on full strength MS medium, either with or without hormones and charcoal. Reduced concentration of MS medium and the presence of charcoal maximized King fern spore germination (Figure ld \& le).

Table 3. Effect of culture media on spore germination of A. evecta (please see methods for description of acronyms)

\begin{tabular}{lccccccccc}
\hline & \multicolumn{10}{c}{ Culture media } \\
\cline { 2 - 9 } & MSc & MSO & $\begin{array}{c}\text { MS1/4 } \\
\mathrm{c}\end{array}$ & FN & $\begin{array}{c}\text { MS } \\
\text { low }\end{array}$ & $\begin{array}{c}\text { MS1/2 } \\
\text { low }\end{array}$ & $\begin{array}{c}\text { MS1/4 } \\
\text { low }\end{array}$ & MM & BB \\
\hline $\begin{array}{l}\text { No. of culture } \\
\text { tubes } \\
\text { inoculated }\end{array}$ & 41 & 42 & 16 & 34 & 16 & 26 & 26 & 12 & 12 \\
\hline $\begin{array}{l}\text { No. of tubes } \\
\text { showing } \\
\text { germination }\end{array}$ & 0 & 0 & 11 & 1 & 0 & 1 & 0 & 3 & 2 \\
\hline $\begin{array}{l}\text { Percentage of } \\
\text { tubes showing } \\
\text { germination }\end{array}$ & 0 & 0 & 69 & 3 & 0 & 4 & 0 & 25 & 17 \\
\hline
\end{tabular}




\section{Role of Light in Germination of A. evecta Spores}

Light played a major role in 'the germination of $A$. evecta spores. Irrespective of soaking treatment, the length of exposure to $\mathrm{NaOCl}$, or the type of medium used, almost all the spores failed to germinate in the absence of light (Table 4).

Gametophytes that grew well in tissue culture conditions produced sporophytes within 6 months (Figure If). The sporophytes were then successfully transplanted and raised in a potting mix.

Table 4 The role of light on spore germination of $A$. evecta

\begin{tabular}{lll}
\hline & Light & Dark \\
\hline Number of tubes inoculated & 170 & 49 \\
\hline Number of tubes showing spore germination & 15 & 2 \\
\hline Percentage of tubes showing spore germination & 9 & $2^{*}$ \\
\hline * Tubes germinated only after the cultures were exposed to light & &
\end{tabular}

\section{DISCUSSION}

Pre-disinfestation treatments are usually beneficial in reducing contamination, to a certain level, without harming the explant. This experiment gave a very useful clue for the use of pre-disinfestation treatment for decontaminating spores of Angiopteris evecta. Contamination percentage was reduced to as low as $3 \%$ when sporangia were soaked in water for 24 hours. It is likely that the bacteria and fungi that were adsorbed onto the fern spores become more susceptible to $\mathrm{NaOCl}$ treatment if they are soaked in water prior to disinfestation.

Prior to soaking of sporangia, the whole material was passed through 106 urn sieve (Treatment 1 ) with the aim of reducing the quantity of material to be disinfested, as it included a considerable amount of sori cases and dried leaf pieces. Sieving did not seem to make any difference to contamination rates both in soaked and unsoaked treatments.

Our results revealed that $2 \% \mathrm{NaOCl}$ is highly effective in disinfesting $A$. evecta spores at both 3 and 5 minutes. These results are in agreement with those of Borelli et al. (1990) who obtained best results with 2\% sodium hypochlorite for Cyathea schanschin and Dicksonia sellowiana spores. In contrast, Goller and Rybczynski (1995) obtained better results when they disinfested intact leaves containing the sori of Cyathea australis with 3\% chloramine and Tween for 30 minutes.

The length of exposure of $A$. evecta spores to sodium hypochlorite also had a considerable bearing on the success of germination. Our results showed that three minutes exposure to sodium hypochlorite reduced contamination to a considerable 
extent whereas, 7 and 9 minutes exposure proved to be lethal as the spores failed to germinate. Based on these results, we recommend the exposure of $A$. evecta spores to high concentration (1-2\%) of NaOClfor short duration ( $<5$ minutes).

The pattern of spore germination in various media compositions appears to reflect the need for low concentrations of mineral nutrients and the presence of charcoal for $A$. evecta spore germination. This observation is in consistence with the findings of Khoo and Thomas (1980), who found that high mineral salt concentrations tended to retard spore germination and sporophyte formation of Adiantum raddianum cv Tassel. However, the current findings contrast with those of Fernandez et al. (1997) who reported that MS full strength liquid media being optimal for growth of Blechnum spicant gametophyte. Apart from MS media, Andersen's media for Cyathea australis (Goller and Rybczynski 1995), Jone's media and Knop's solution, respectively, for Cyathea schanschin and Dicksbnia solviana (Borelli et al. 1990) and Knudson's media for Cyathea spinulosa (Agrawal et al. 1993) have also been advocated. Similar to our findings, Wardle et al. (1998) recommended the use of charcoal for the spore germination. Spores are analogous to seeds and they contain all the required nutrients for early growth, therefore it can be justified to use low nutrient media during initial stages of germination.

Light is an important factor and it plays a significant role in the germination of A. evecta spores. The results of this study concur with the field observations (S. Marsterson; Department of E.P.A., Rockhampton, Pers. com.) where the King fern seedlings usually occur in patches of rainforests that have been exposed to light possibly due to fire or other sources of damage to canopy. Light has been found to govern the development stage of whole gametophyte (Turnwald et al. 1999). Kiss and Kiss (1998) reported that light frequency in the red region is found to promote spore germination more than in far-red region. Light not only regulates the growth mechanism in haploid gametophyte, but it also affects development of sporophyte due to involvement of a photoreceptor phytochrome (Christensen et al. 1998). Presence of light has been shown to increase nuclear DNA and this increase is known to have an influence on fern spore germination (Raghavan 1993).

This study has demonstrated the importance of soaking of $A$. evecta spores to minimize contamination, sensitivity of King fern spores to high mineral concentration of the media and the need for light and charcoal for its spore germination. These data highlight the desirable conditions for disinfestation and germination of King fern spores.

\section{REFERENCES}

Agrawal DC, SS Pawar, AF Mascarenhas. 1993. Cryopreservation of spores of Cyathea spinulosa Wall, ex. Hook. f. - an endangered tree fern. J Plant Physiol 142: 124-126.

Amoroso CB, VB Amoroso. 1998. Spore culture studies on some economic ferns of Mindanao, Philippines. Acta Horticulturae 461: 231-235. 
In vitro propagation of Angiopteris evecta using spores — Damien Cupitt et al.

Bernabe N, G Williams-Linera, M Palacios-Rios. 1999. Tree ferns in the interior and at the edge of a Mexican Cloud forest remnant: spore germination and sporophyte survival and establishment. Biotropica31: 83-88.

Bischoff H, HC Bold .1963. Some soil algae from Enchanted Rock and related algal species. Phycological studies IV. University of Texas Publication No. 6318, Austin p. 9-13.

Blomberry AM, B Maloney .1994. Propagating Australian plants. Kangaroo Press, NSW. 112 p.

Borelli FP, CEF Castro, LAP De Matthes, AFC Tombolato, V Nagai .1990. Propagacao de pteridofitas in vitro e in vivo atraves de esporos. Bragantia 49: 205-219.

Christensen S, Y Tokuoka, J Silverthorne, M Wada. 1998. Phytochrome regulation of expression of mRNA encoding the major light-harvesting chlorophyll a/b-binding proteins of photosystem II in the haploid phase ofAdiantum capillus-veneris. Plant and Cell Physiology 39: 647-654.

De Fossard RA. 1981. Tissue culture for plant propagators. The University of New England. Armidale, NSW. p. 10-11.

Dong L, XH Su. 1993 .Study on the spore propagation of the ostrich fern, Matteuccia struthiopteris Todaro. Acta Horticul.turae Sinica 20: 274-278.

Fernandez H, AM Bertrand, I Feito, R Sancheztames. 1997. Gametophyte culture in vitro and antheridiogen activity in Blechnum spicant. Plant Cell Tissue and Organ Culture 50: 71-74.

Goller K, JJ Rybczynski. 1995. In vitro culture used for woody fern Cyathea australis (R.Br.) Domin vegetative propagation. Acta Societatis Botanicorum Poloniae 64: 13-17.

Khoo SI, MB Thomas. 1980. Studies on the germination pf fern spores. The Plant Propagator 26: 11-15.

Kiss HG, JZ Kiss. 1998. Spore germination in populations of Schizaea pusilla from New Jersey and Nova Scotia. International Journal of Plant Sciences 159: 848-852.

Manickam VS, V Irudayaraj. 1992. Pteridophyte flora of the Western Ghats - South India B. I. Publications, New Delhi p. 56-57.

Murashige T, F Skoog. 1962. A revised medium for rapid growth and bioassays with tobacco tissue cultures. Physiologia Plantarum 15: 473-497

Raghavan V .1993. Chloroplast activities of dark-imbibed and photo induced spores of the fern Onoclea-sensibilis. Protoplasma 175: 75-84.

Turnwald S, R Scheuerlein, M Furuya .1999. Phytochrome-dependent modulation and re-induction of growth of the first rhizoid in Dryopteris paleacea Sw. Planta. 208: 98-106.

Wardle DA, O Zackrisson, MC Nilsson. 1998. The charcoal effect in Boreal forests: mechanisms and ecological consequences. Oecologia 115: 419-426. 